\title{
Penerapan Teknik Cognitive Behaviour Group Therapy dalam Meningkatkan Perilaku Asertif pada Remaja Awal
}

\section{Application of Cognitive Behaviour Group Therapy Techniques in Improving Assertive Behavior in Early Adolescents}

\author{
Fachrun Naja Maulidia, Efriyani Djuwita \\ Fakultas Psikologi, Universitas Indonesia, Depok, Indonesia \\ Email: fachrunnajamaulidia@gmail.com
}

\section{KATA KUNCI Cognitive Behaviour Group Therapy (CBGT), Asertif. \\ KEYWORDS Cognitive Behaviour Group Therapy (CBGT), Assertiveness.}

ABSTRAK Asertif adalah salah satu aspek krusial yang mempengaruhi kemampuan interaksi sosial pada remaja. Kendati demikian, beberapa masalah mengenai perilaku asertif sering kali ditemui terutama di lingkungan sekolah. Guru sering kali mengeluhkan siswa cukup pasif selama pembelajaran. Sementara itu, siswa lainnya ditemukan sering berkomunikasi secara agresif hingga terlibat dalam pertengkaran. Salah satu upaya yang dilakukan untuk mengatasi masalah tersebut adalah dengan memberikan pelatihan asertif. Penelitian ini bertujuan untuk mengetahui bagaimana efektivitas Penerapan Cognitive Behaviour Group Therapy (CBGT) dalam meningkatkan perilaku asertif pada remaja awal. Penelitian ini menggunakan metode kuasi eksperimental dengan model one group pretest-posttest design. Pada penelitian ini, terdapat tujuh sesi pertemuan termasuk follow-up yang setiap sesinya menghabiskan waktu sekitar 45-60 menit. Partisipan dalam penelitian ini berjumlah tujuh siswa kelas enam sekolah dasar (SD) dengan kisaran usia 11-13 tahun. Pengukuran efektivitas dalam penelitian ini menggunakan alat ukur Assertiveness Formative Questionnaire dan rating berupa penilaian partisipan dalam melakukan perilaku asertif. Data dianalisis dengan statistik deskriptif, yaitu membandingkan mean score partisipan pada masing-masing aspek pengetahuan dan penilaian di tahap pre-test dan post-test. Hasil penelitian menunjukkan bahwa penerapan cognitive behaviour group therapy (CBGT) efektif dalam meningkatkan perilaku asertif pada remaja awal terutama pada aspek kognitif yang berkaitan dengan pengetahuan dan persepsi (penilaian) partisipan. Adapun dengan meningkatnya kemampuan tersebut, partisipan menjadi lebih mampu berpikir positif dan berani mempraktikan perilaku asertif dalam kehidupan sehari-hari. 
ABSTRACT Assertive is one of the crucial aspect that affects the ability of social interaction in adolescents. Nevertheless, some problems regarding assertive behavior are often encountered especially in school environments. Teachers often complain about students being passive enough during learning process. Meanwhile, other students were found to communicate aggressively until they got into an altercation. One of the attempts made to solve the problem is to provide assertive training. This study aims to find out how effective the Application of Cognitive Behaviour Group Therapy (CBGT) in improving assertive behavior in early adolescents. This study used quasi-experimental method with one group pretest-post test design model. In this study there were 7 sessions of meetings, including follow-ups that each session took about 45-60 minutes. Participants were 7 elementary school students with an age range of 11-13 years. Measurement of effectiveness in this study using Assertiveness Formative Questionnaire and rating measurement in the form of assessment of participants in conducting assertive behavior. The data were analyzed by descriptive statistics, namely comparing the participants' mean scores on each aspect of knowledge and assessment in the pre-test and post-test stages. The results showed that the application of cognitive behaviour group therapy (CBGT) was effective in improving assertive behavior in early adolescents, especially in cognitive aspects related to the knowledge and perception of participants. Meanwhile, with this increased ability, participants become more able to think positively and dare to practice assertive behavior in their daily lives.

\section{PENDAHULUAN}

Remaja adalah fase penting dalam perkembangan individu. Pada fase ini, remaja memiliki banyak tuntutan baru yaitu mencari identitas diri dan menjalin interaksi sosial yang berkualitas agar diterima oleh lingkungan (Ragelienè, 2016; Vagos, Pereira, 2010). Remaja yang berhasil mencapai tugas perkembangan tersebut nantinya akan memiliki keberhargaan diri dan kesejahteraan psikologis yang baik. (Goswami, 2011).

Salah satu aspek yang mempengaruhi interaksi sosial yang berkualitas pada remaja adalah kemampuan asertif (Sitota, 2018). Tunner (1992, dalam Sitota, 2018) mendefinisikan asertif sebagai kemampuan untuk mengkomunikasikan pendapat, kebutuhan dan perasaan secara langsung, jujur, dan tepat. Individu yang asertif ditemukan lebih mampu memahami hak atau perasaan diri sendiri dan orang disekitarnya. Mereka juga dapat mengungkapkan permintaan, pendapat, kritik atau penolakan dengan cara yang efektif tanpa menyakiti diri sendiri ataupun orang lain.

Secara lebih luas, asertif berdampak signifikan terhadap kesuksesan remaja di sekolah. Hasil penelitian menunjukkan bahwa asertif dapat meningkatkan motivasi belajar, prestasi akademik, self esteem, dan self efficacy (Sitota, 2018; Parray, \& Kumar, 2017). Sebaliknya, remaja yang tidak asertif ditemui cenderung tidak percaya diri, cemas, atau depresi (Ghodrati dkk., 2016, dalam Sitota, 2018; Parray \& Kumar, 2017).

Umumnya, Individu yang tidak asertif akan menampilkan dua karakteristik perilaku yaitu, pasif dan agresif. Pada individu yang pasif, mereka merasa kebutuhan orang lain lebih penting dari dirinya dan cemas terhadap penolakan 
orang lain. Sementara pada individu yang agresif, biasanya perilaku mereka diliputi kemarahan serta permusuhan. Mereka tidak segan menggunakan ancaman, berbicara dengan kasar, menatap dengan permusuhan, dan selalu mementingkan dirinya sendiri meskipun merugikan orang lain (Hargie, 2004, dalam Kashani \& Bayat, 2010).

Hasil penelitian lain juga menemukan bahwa perilaku tidak asertif berpengaruh signifikan terhadap proses belajar. Dalam hal ini, siswa juga dapat bersikap pasif atau agresif selama pembelajaran. Sikap pasif menyebabkan siswa merasa malu untuk berkomunikasi dengan orang lain. Mereka juga takut untuk bertanya kepada guru mengenai pelajaran, kurang berani membantah pendapat orang lain saat diskusi, dan kurang mampu berpartisipasi dalam kegiatan diskusi (Asrowi \& Muya, 2013). Sementara, sikap agresif dapat terlihat melalui aspek verbal dan non verbal yang tidak sesuai. Siswa yang agresif lebih sering menggunakan kalimat kasar atau menyakiti orang lain. Mereka cenderung mendominasi atau tidak mau mengalah, sering menyalahkan orang lain, dan bereaksi negatif terhadap situasi hingga dapat melakukan kekerasan secara fisik (Ogunyemi \& Olagbaju, 2020).

Berdasarkan hasil wawancara personal terhadap guru di salah satu Sekolah Dasar Islam di Bekasi pada tanggal 17 Juli 2019 ditemukan bahwa terdapat masalah mengenai asertivitas pada siswa. Dalam hal ini, sebagian besar siswa menunjukkan perilaku pasif selama proses pembelajaran. Menurut guru, siswa cenderung lebih banyak diam, menggunakan nada suara yang pelan dan kurang berinisiatif atau aktif untuk bertanya atau menjawab pertanyaan guru. Sementara itu, sebagian lainnya tergolong sulit diajak bekerja sama saat diskusi kelompok, sering kali menginterupsi guru untuk hal yang tidak relevan dan menolak ketika diberikan tugas untuk maju ke depan. Menurut guru, telah banyak upaya dilakukan untuk mengatasi masalah tersebut seperti, memberikan reward (nilai dan hadiah) bagi siswa yang berperan aktif dalam proses pembelajaran. Kendati demikian, upaya tersebut cenderung tidak efektif karena masih banyak siswa yang tetap bersikap pasif dalam proses pembelajaran sehingga membuat guru cukup kesulitan untuk memberikan penilaian secara maksimal sesuai dengan tuntutan kurikulum 2013.

Berdasarkan kurikulum 2013, siswa dituntut untuk bersikap aktif, kritis, kreatif, dan berani mengekspresikan dirinya sesuai dengan nilai luhur dan spiritual (Kementerian Pendidikan Nasional, 2014). Akan tetapi, berbagai sikap siswa di atas tidak mencerminkan sikap tersebut. Dalam hal ini, siswa menunjukkan perilaku asertif yang cenderung rendah.

Salah satu faktor yang ditemukan mempengaruhi perilaku asertif seseorang adalah budaya. Dalam hal ini, nilai-nilai dan kepercayaan yang dimiliki seseorang berkaitan dengan bagaimana seseorang berperilaku (Eskin, 2003). Lebih spesifik, penelitian menunjukkan bahwa perilaku asertif ditemukan lebih tinggi pada orang Eropa danAmerika dibandingkan Asia (Eskin, 2003; Tripathi et al., 2010). Hal tersebut karena negara Eropa atau Amerika memiliki budaya individualistik yang menjunjung nilai pribadi dan pengekspresian diri secara terbuka. Sedangkan, negara di Asia lebih lekat dengan budaya kolektivitas yang menjunjung tinggi norma sosial. Pada budaya kolektivitas, individu juga memiliki ekspektasi spesifik saat berinteraksi sosial. Mereka cenderung berperilaku sesuai dengan apa yang dipikirkan dan dilakukan oleh jaringan sosial meskipun harus mengabaikan kemauan, nilai dan kebutuhan diri sendiri (Yoshioka, 2000, dalam Eskin, 2003; Menon \& Morris, 2001; Cheng \& Chun, 2008).

Mengacu pada hal tersebut maka, diperlukan sebuah upaya untuk mendorong siswa meningkatkan keaktifan dan keasertivitasan mereka di dalam kelas. Salah satu caranya adalah dengan memberikan intervensi berupa pelatihan 
asertivitas (Çeçen-Eroğul \& Zengel, 2009). Pelatihan yang diberikan berfokus pada dua komponen utama dari perilaku asertif yaitu, kemampuan untuk mengungkapkan keinginan, pikiran dan kebutuhan (express) serta penghargaan terhadap orang lain (respect) (Gaumer Erickson, Soukup \& Noonan, 2018). Dengan meningkatnya kedua komponen tersebut remaja diharapkan mampu membangun hubungan berkualitas dengan orang lain, memiliki kecemasan yang rendah saat berinteraksi sosial, percaya diri dan dapat berperilaku efektif (Parray \& Kumar, 2017).

Salah satu teknik yang sering digunakan untuk melatih asertif adalah metode cognitive behavioral therapy (CBT) (Zulkaida, 2014). Pemilihan metode ini dirasa tepat karena masalah asertif bukan hanya berkaitan dengan aspek keterampilan komunikasi saja (kesulitan memahami dan mengomunikasikan keinginan). Akan tetapi, berhubungan juga dengan adanya disfungsi kognitif (Heimberg \& Becker, 1981, dalam Speed, Goldstein, \& Goldfried, 2017). Oleh sebab itu, pelatihan asertif menggunakan metode CBT dianggap efektif karena menyasar kedua aspek asertivitas yaitu keterampilan perilaku dan restrukturisasi kognitif (Zulkaida, 2014). Dalam hal ini, keterampilan perilaku betujuan untuk melatih kemampuan berkomunikasi secara tepat pada aspek verbal dan non verbal melalui ketepatan sikap tubuh, kontak mata, volume suara, intonasi hingga keterampilan untuk berkata tidak. Sedangkan restrukturisasi kognitif bertujuan untuk memperbaiki kesalahan berpikir yang menyebabkan meunculnya masalah kecemasan (Speed dkk., 2017; Parray \& Kumar, 2017).

Pada pelaksanaannya, penerapan pendekatan CBT akan dilakukan dengan berlandaskan prinsip kognitif. Dalam hal ini, kognitif diyakini memiliki peran yang signifikan dalam menentukan reaksi emosional dan perilaku seseorang. Dengan kata lain, perilaku seseorang sangat ditentukan oleh pemikiran, kepercayaan dan interpretasi mereka terhadap suatu situasi (Westbrook dkk., 2011). Mengacu pada hal tersebut, prinsip kognitif dalam intervensi ini akan diimplementasikan melalui psikoedukasi. Steward dkk. (2007) menyebutkan bahwa psikoedukasi adalah salah satu cara yang digunakan untuk mengajarkan remaja keterampilan spesifik dalam kehidupan sehari-hari. Pada intervensi ini, psikoedukasi bertujuan untuk meningkatkan pengetahuan dan persepsi partisipan dalam berperilaku asertif.

Penerapan prinsip CBT dalam intervensi ini akan dilakukan secara kelompok (cognitive behavioral group therapy/ CBGT). Morganett (1990, dalam Çeçen-Eroğul, \& Zengel, 2009) mengemukakan bahwa program intervensi kelompok sangat bermanfaat untuk remaja karena dapat memberikan suasana penerimaan, semangat dan menyediakan lingkungan yang aman untuk perilaku baru. Dengan pelatihan kelompok, remaja diharapkan tidak segan mempraktikan perilaku baru yang telah diajarkan. Sejalan dengan pendapat tersebut, penelitian di Iran oleh Ilkhchi dkk. (2011) telah membuktikan bahwa penerapan metode CBT secara kelompok atau cognitive-behavioral group therapy (CBGT) tergolong efektif untuk meningkatkan self efficacy dan asertivitas remaja sekolah menengah yang mengalami kecemasan.

Secara umum penelitian Ilkhchi dkk. (2011) dan penelitian ini memiliki kesamaan latar belakang budaya yaitu berasal dari Asia dengan budaya kolektivisme. Kendati demikian, bukan berarti budaya di Iran dan Indonesia itu bersifat homogen. Dalam hal ini, budaya pada setiap negara itu bersifat unik karena terbentuk melalui perbedaan karakteristik individu yang dipengaruhi oleh berbagai macam latar belakang dan posisi yang beragam dalam stuktur sosial (Green, Deschamps, \& Paez, 2005). Lebih khusus, Indonesia memiliki keanekaragaman budaya yang sangat luas yang mana hal tersebut juga mempengaruhi perilaku asertif di dalam masyarakatnya. Sebagai contoh, budaya Jawa identik dengan sikap 
pemalu dan sungkan untuk berterus terang (Idrus, 2004), sedangkan budaya Batak atau Minang dikenal mampu bersikap asertif dalam mengungkapkan keinginannya (Andayani \& Mardianto, 2017). Mengacu pada hal tersebut maka, penelitian di Indonesia belum tentu akan menghasilkan temuan yang serupa dengan penelitian Illkchi dkk. (2011) di Iran.

Target partisipan dalam penelitian ini juga berbeda. Dalam penelitian ini, partisipan merupakan remaja awal yang yang berada di jenjang kelas enam SD. Pada jenjang ini, siswa juga dihadapkan pada tuntutan untuk mempersiapkan diri dalam proses transisi ke SMP, yang mana mereka akan menghadapi perubahan dalam lingkungan sosial dan sekolah yang rentan mengalami masalah. Oleh sebab itu, kemampuan sosial menjadi salah satu prediktor penting yang akan menentukan kesuksesan siswa dalam melakukan transisi ke sekolah baru (Howard \& Johnson, 2004).

Mengacu pada hal tersebut maka peneliti tertarik untuk meneliti efektivitas prinsip CBGT dalam meningkatkan kemampuan asertivitas remaja awal yang di salah satu Sekolah Islam di Bekasi yang mengalami asertivitas rendah. Adapun, pemberian intervensi ini diharapkan dapat membantu remaja meningkatkan kemampuan komunikasinya agar dapat beradaptasi lebih baik di sekolahnya saat ini atau sekolah barunya nanti.

\section{METODE PENELITIAN Desain}

Penelitian ini menggunakan metode kuasi eksperimental dengan model one group pretest-posttest design. Pada model ini, tidak terdapat kelompok kontrol yang mana pengukuran terhadap variabel yang diukur dilakukan sebelum dan sesudah diberikannya intervensi (Privitera \& Delzell, 2019).

\section{Partisipan}

Partisipan dalam penelitian ini didapatkan dengan menggunakan metode purposive sampling yang mana partisipan dipilih berdasarkan karakteristik yang telah ditetapkan peneliti. Dalam hal ini, peneliti melakukan screening menggunakan alat ukur Assertiveness Formative Questionnaire. Adapun screening ini bertujuan untuk melihat tingkat asertivtias partisipan. Partisipan dengan tingkat asertif yang rendah dipilih untuk mengikuti penelitian ini (skor <62). Selanjutnya, dilakukan wawancara kepada guru untuk mendapatkan gambaran mengenai perilaku asertif partisipan. Akhirnya didapatkan tujuh partisipan dengan rentang usia 11-13 tahun yang terlibat dalam penelitian ini.

\section{Instrumen}

Pada tahap screening, alat ukur yang digunakan dalam penelitian ini adalah Assertiveness Formative Questionnaire yang diadaptasi dari diadaptasi dari Gaumer Erickson dkk. (2018). Alat ukur ini mengukur dua komponen asertif yaitu kemampuan untuk mengungkapkan keinginan, pikiran, kebutuhan (express), dan penghargaan terhadap orang lain (respect) (Gaumer Erickson dkk., 2018). Alat ukur ini terdiri dari 20 item dan diantaranya terdapat lima pernyataan negatif. Alat ukur ini menggunakan skala Likert lima poin yang mencakup 1 (sangat tidak sesuai) hingga 5 (sangat sesuai). Hasil dari alat ukur ini menunjukkan bahwa semakin tinggi skor yang diperoleh maka semakin asertif siswa tersebut. Skor untuk asertivtias yang tinggi berkisar antara 75100 sedangkan skor untuk asertivitas yang rendah adalah 18-62. Sementara itu, alat ukur ini juga tergolong reliabel dalam mengukur asertif dengan skor $\alpha=0,733$ (Gaumer Erickson dkk., 2018).

Pada tahap intervensi, pengukuran dilakukan terhadap dua aspek kognitif yaitu pengetahuan dan persepsi. Pada aspek pengetahuan, partisipan diminta mengerjakan soal yang mencakup pengetahuan mengenai perilaku asertif. 
Soal tersebut terdiri dari dua bagian. Pada bagian A terdiri dari enam soal pilihan ganda (nomor 1-6) sedangkan pada bagian B berisi empat soal uraian (7-10). Pada bagian A, jawaban benar akan bernilai satu sedangkan jika salah akan bernilai nol. Sementara pada bagian B, penilaian sangat tergantung pada jawaban partisipan. Pada soal nomor tujuh, partisipan akan memiliki nilai nol jika tidak mampu menjawab dengan benar dan maksimal lima jika mampu memberikan lima contoh yang diminta. Sedangkan pada soal nomor 8-10 bernilai nol jika tidak mampu menjawab dengan benar dan maksimal tiga jika mampu menjawab tiga contoh dengan benar. Nantinya, skor pada bagian A dan B akan digabungkan lalu dibagi dua sehingga total maksimal nilai yang diperoleh partisipan adalah 10 .

Pada aspek persepsi dalam melakukan perilaku asertif, partisipan diminta melakukan penilaian terhadap kemampuan asertifnya melalui self rating. Rating tersebut diadaptasi dari modul Assert Yourself yang dikembangkan oleh Centre for Clinical Intervention (CCI). Skala rating ini mencakup beberapa aspek asertivitas yang sesuai dengan tujuan intervensi yaitu, kemampuan berkata tidak, mengungkapkan pendapat, meminta tolong, mengungkapkan perasaan marah, mengungkapkan kasih sayang, memulai pembicaraan atau mempertahankannya dan mengungkapkan kebutuhan atau keinginan. Nantinya, partisipan diminta untuk menilai kemampuan asertifnya pada beberapa situasi seperti ketika berhadapan dengan orang tua, saudara, teman laki-laki, teman perempuan dan guru. Partisipan kemudian akan diminta untuk menilai perilaku asertifnya dari nilai nol sampai dengan lima. Nilai nol berarti partisipan dapat dengan mudah berperilaku asertif tanpa hambatan. Sedangkan nilai lima berarti partisipan sama sekali tidak bisa berperilaku asertif pada situasi tersebut.

\section{Prosedur}

Sebelum intervensi berlangsung, partisipan melakukan Berdasarkan hasil screening awal dengan alat ukur Assertiveness Formative Questionnaire dan diperoleh 15 partisipan yang tergolong memiliki tingkat asertivitas yang rendah. Selanjutnya, peneliti mencari informasi tambahan mengenai asertivitas 15 siswa tersebut melalui wawancara dengan guru. Beberapa hal yang ditanyakan kepada guru adalah mengenai kemampuan berpikir siswa (penalaran), keaktifan, inisiatif dan gaya komunikasi siswa selama di kelas. Hasilnya, diperoleh 10 partisipan yang terlibat dalam intervensi ini. Adapun lima partisipan lainnya tidak terlibat dalam intervensi ini karena dua partisipan mengalami kesulitan dalam menangkap pelajaran atau ketika berdiskusi, dua partisipan tidak mendapatkan izin dari orang tua, dan satu partisipan lainnya menolak untuk terlibat dalam intervensi.

Pada akhirnya intervensi dimulai dengan 10 orang partisipan. Akan tetapi, jumlah tersebut semakin berkurang menjadi tujuh orang karena tiga partisipan lainnya tidak mengikuti kegiatan dari awal hingga akhir seperti, tidak hadir di sekolah, datang terlambat setiap sesi, selalu tidak membawa buku modul dan sering kali tidak mengerjakan tugas yang diberikan.

Program intervensi ini menerapkan pendekatan CBGT untuk meningkatkan perilaku asertif. Pendekatan ini tergolong komprehensif karena menggunakan dua teknik yaitu, teknik kognitif untuk merestrukturisasi kognitif dan teknik perilaku untuk melatih keterampilan perilaku partisipan agar lebih efektif (Duckworth \& Mercer, 2006).

Sebelum memulai intervensi, peneliti melakukan pengukuran terhadap aspek kognitif partisipan yang berkaitan dengan perilaku asertif. Selanjutnya, intervensi dilaksanakan dengan menerapkan teknik kognitif. Dalam hal ini, partisipan diajak memperluas pandangan mereka untuk mencari solusi atas permasalahan yang sedang dihadapi (Padesky, 1993, dalam 
Fenn \& Byrne, 2013). Cara yang dilakukan peneliti adalah mengajarkan partisipan mengenai cognitive triangle atau segitiga $\mathrm{P}$. Dengan cara tersebut, partisipan dapat lebih mudah memahami hubungan antara pikiran, perasaan dan perilaku saat ini secara konkret (Assigana dkk., 2014).

Setelah memahami pikiran, perasaan dan perilakunya partisipan kemudian diajak untuk melakukan restrukturisasi kognitif. Dengan teknik ini, partisipan diajarkan cara mengidentifikasi, mengevaluasi dan memodifikasi pikiran, penilaian dan keyakinan maladpatif sehingga dapat menghasilkan alternatif perspektif yang mendorong perubahan kognitif (Clark, 2013). Untuk mempermudah proses restrukturisasi kognitif, partisipan diminta mengerjakan thought record. Dengan thought record, klien diharapkan dapat lebih mudah mengakses pikirannya sehingga mereka dapat menyadari dan memahami dampak pikiran terhadap suasana hati dan perilaku mereka (Fenn \& Byrne, 2013).

Pada teknik perilaku, partisipan diminta melakukan behavioral experiments. Dengan teknik ini, seseorang dapat menguji prediksi atau pikiran buruk mereka terhadap suatu hal yang mungkin terjadi. Bersamaan dengan itu, teknik ini juga dapat membantu klien belajar bertoleransi dengan kecemasannya. Selain itu, partisipan juga diajarkan cara melakukan relaksasi progresif atau latihan pernapasan. Adapun teknik ini bertujuan untuk mengurangi ketegangan yang disebabkan oleh kecemasan pada partisipan saat menampilkan perilaku baru (Fenn \& Byrne, 2013).

\section{Program Intervensi}

Pada pelaksanaannya, intervensi ini terdiri dari tujuh sesi pertemuan termasuk follow-up. Pada setiap sesinya, kegiatan dilaksanakan dengan durasi 45 menit sampai 60 menit. Kegiatan intervensi ini terdiri dari psikoedukasi dengan metode ceramah, diskusi, role play, pengisian lembar kerja dan pekerjaan rumah (PR).
Partisipan juga diberikan games sebelum pelaksanaan atau di tengah jeda materi untuk mempertahankan semangat dan menghindari kebosanan.

Program intervensi ini dilaksanakan dengan berpedoman pada modul yang telah diadaptasi dari modul Assert Yourself. Modul tersebut disusun oleh Michel (2008) dan terdiri dari 10 materi. Kendati demikian, dengan mempertimbangkan usia dan jenis perilaku yang dilatih, maka hanya 7 dari 10 materi yang digunakan dalam intervensi ini. Adapun, tujuh materi pada setiap sesinya dapat dilihat pada Tabel 1 .

\section{Teknik Analisis Data}

Analisa data dalam penelitian ini dilakukan secara deskriptif dan juga diuji secara statistik. Pengujian deskriptif, dilakukan dengan membandingkan mean score partisipan pada masing-masing aspek pengetahuan dan penilaian di tahap pre-test dan post-test. Jika terdapat peningkatan maka artinya, intervensi ini efektif dalam meningkatkan perilaku asertif siswa. Sebaliknya, jika terjadi penurunan maka intervensi ini tergolong tidak efektif dalam meningkatkan perilaku asertif

Sementara itu, untuk teknik pengujian statistik yang digunakan dalam penelitian ini adalah Wilcoxon signed-rank, paired sample t-test, dan Friedman test. Secara lebih rinci, Wilcoxon signed-rank digunakan untuk menguji aspek pengetahuan pada saat pre-test dan posttest. Wilcoxon signed-rank merupakan prosedur tes non parametrik yang digunakan untuk menguji data berpasangan yang tidak terdistribusi secara normal (Woolson, 2007). Sementara itu, pengujian statistik paired sample t-test digunakan untuk menguji aspek persepsi partisipan. Dalam hal ini, paired sample t-test dipilih karena uji statistik ini cocok untuk menganalisis perbandingan antar kelompok (pre dan post) dari sampel berpasangan yang terdistribusi normal (Ross \& Willson, 2017). Sedangkan pada fase follow-up uji statistik yang digunakan adalah Friedman test yang mana uji ini cocok untuk 
menganalisis data berpasangan yang memiliki lebih dari dua sampel (pre, post, dan follow-up) (Santoso, 2006).

Tabel 1

Modul dan Teknik CBGT

\begin{tabular}{|c|c|c|c|}
\hline Teknik CBT & Sesi & Modul & Pembahasan \\
\hline & & e-test & $\begin{array}{l}\text { Pengukuran dan tujuan } \\
\text { penelitian }\end{array}$ \\
\hline \multirow[t]{2}{*}{$\begin{array}{l}\text { Identifikasi Pola Berpikir dan } \\
\text { Perilaku melalui Cognitive Triangle }\end{array}$} & Sesi 1 & Modul 1 & $\begin{array}{l}\text { Pengertian Asertif (What is } \\
\text { Assertiveness) }\end{array}$ \\
\hline & Sesi 2 & Modul 2: & $\begin{array}{l}\text { Mengenali Perilaku Asertif (How } \\
\text { to Recognize Assertive Behavior) }\end{array}$ \\
\hline $\begin{array}{l}\text { Restrukturisasi Kesalahan Berpikir } \\
\text { melalui Thought Record }\end{array}$ & Sesi 3 & Modul 3 & $\begin{array}{l}\text { Berpikir Asertif (How to Think } \\
\text { More Assertively) }\end{array}$ \\
\hline \multirow{6}{*}{$\begin{array}{l}\text { Latihan Relaksasi dan Menerapkan } \\
\text { Perilaku Baru melalui Behavioral } \\
\text { Experiment }\end{array}$} & \multirow[t]{2}{*}{ Sesi 4} & Modul 4 & $\begin{array}{l}\text { Teknik Dasar Asertif (How to } \\
\text { Behave More Assertively) }\end{array}$ \\
\hline & & Modul 5 & $\begin{array}{l}\text { Mengurangi Ketegangan Fisik } \\
\text { (Reducing Physical Tension) }\end{array}$ \\
\hline & Sesi 5 & Modul 6 & $\begin{array}{l}\text { Berkata Tidak secara Asertif } \\
\text { (How to Say No Assertively) }\end{array}$ \\
\hline & Sesi 6 & Modul 10 & $\begin{array}{l}\text { Rencana Aksi (Putting it All } \\
\text { Together) }\end{array}$ \\
\hline & \multicolumn{2}{|c|}{ Post-test } & Pengukuran \\
\hline & \multicolumn{2}{|c|}{ Follow-up } & Pengukuran dan Debriefing \\
\hline
\end{tabular}


ANALISIS DAN HASIL

Berdasarkan hasil uji statistik menggunakan Wilcoxon signed-rank ditemukan bahwa pelatihan asertif menggunakan prinsip CBT secara efektif berperan dalam mengubah tingkat pengetahuan partisipan mengenai asertivitas $(\mathrm{Z}=-2.379, p=0.017)$. Adapun, hasil tersebut juga didukung dengan analisis deskriptif menggunakan mean score yang menunjukkan bahwa terdapat perubahan skor pengetahuan pada seluruh partisipan saat sebelum $(\mathrm{M}=3)$ dan sesudah intervensi $(\mathrm{M}=6.29)$.

Secara umum, semua partisipan telah memahami bahwa asertif adalah kemampuan komunikasi atau kemampuan untuk mengungkapkan pikiran dan perasaan secara tepat. Partisipan juga mulai memahami cara melakukan penolakan jika berhadapan pada situasi tertentu. Partisipan juga mulai mengetahui sikap non verbal yang dapat ditampilkan jika berkomunikasi dengan orang lain seperti, harus menatap mata, mendengarkan secara seksama ketika berkomunikasi, berbicara dengan tenang, dan lembut tanpa kemarahan. Selain itu, partisipan juga mulai mampu mengidentifikasi faktor yang menyulitkan dalam berperilaku asertif. Mayoritas penyebabnya adalah rasa malu, takut dijauhi, takut dibully, ada rasa tidak enak atau khawatir membuat kecewa. Untuk mengatasi situasi tersebut partisipan mencoba untuk bersikap percaya diri, berusaha tenang dengan relaksasi atau menarik napas dalam dan memberanikan diri untuk mengungkapkan pendapat.
Pengukuran terhadap aspek pengetahuan kembali diukur pada sesi follow-up. Skor yang diperoleh pada sesi tersebut kemudian diukur menggunakan Friedman Test. Hasil menunjukkan bahwa terdapat perbedaan rata-rata hasil pengetahuan pada saat pre-test, post-test dan follow up (Chi-Square $=10.160$, $p=0.006$ ). Hasil tersebut menunjukkan bahwa intervensi dengan pendekatan CBGT memberikan dampak signifikan terhadap pengetahuan siswa mengenai keterampilan asertif.

Selanjutnya, analisis deskriptif juga menunjukkan bahwa terdapat penurunan mean score pada partisipan ( $\mathrm{M}$ pre $=3 ; \mathrm{M}$ post $=6.29$ dan $\mathrm{M}$ follow-up= 6.14). Jika diamati secara individual terlihat bahwa hasil pada sesi follow up ini menunjukkan perubahan yang beragam. Terdapat dua partisipan yang mengalami kestabilan tingkat pengetahuan, dua orang lainnya mengalami penurunan tingkat pengetahuan dan tiga partisipan lainnya yang mengalami peningkatan pengetahuan mengenai keterampilan asertif. Hasil tersebut menunjukkan bahwa beberapa partisipan yang mengalami peningkatan atau hasil yang stabil cenderung masih mengingat informasi mengenai perilaku asertif yang diberikan selama sesi intervensi. Sedangkan beberapa lainnya, cenderung melupakan apa yang disampaikan selama sesi intervensi. Adapun gambaran lebih rinci mengenai hasil pre-test, post-tes dan follow-up dapat dilihat pada Gambar 1.

Gambar 1

Hasil Pre-Test, Post-Test dan Follow-Up Tingkat Pengetahuan

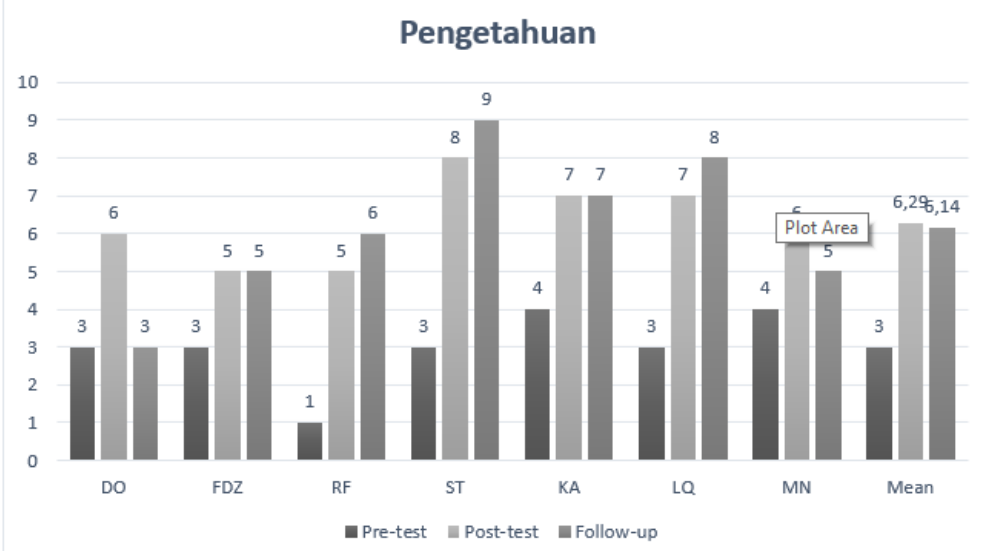


Pada aspek persepsi dalam melakukan perilaku asertif, data partisipan diuji menggunakan paired sample t-test. Hasil menunjukkan bahwa pelatihan asertif menggunakan prinsip CBGT secara efektif berperan dalam mengubah persepsi individu dalam melakukan perilaku asertif terhadap orang tua $(\mathrm{t}=5.290, p=0.002)$ dan guru ( $\mathrm{t}=3.166, p=0.019)$. Sementara itu, hasil lainnya juga menunjukkan bahwa pelatihan asertif menggunakan prinsip CBGT tidak berperan dalam mengubah persepsi individu dalam melakukan perilaku asertif terhadap teman laki-laki $(\mathrm{t}=1.210, \quad p=0.272)$, teman perempuan $(\mathrm{t}=0.761, p=0.475)$ dan saudara $(\mathrm{t}=0.319$, $p=0.760)$.

Secara deskriptif, pada umumnya, partisipan berpikir sulit untuk melakukan perilaku asertif terhadap saudara dalam hal kemampuan berkata tidak, mengungkapkan pendapat, meminta tolong, mengungkapkan perasaan marah, mengungkapkan kasih sayang, memulai pembicaraan atau mempertahankannya dan mengungkapkan kebutuhan atau keinginanannya (FDZ, RF, $\mathrm{KA}$, dan MN). Sementara itu, pada teman laki-laki, partisipan berpikir sulit untuk melakukan perilaku asertif dalam hal mengungkapkan perasaan marah, mengungkapkan pendapat dan memulai pembicaraan (DO dan KA). Sedangkan pada teman perempuan, beberapa partisipan kesulitan untuk berkata tidak dan memulai pembicaraan (FDZ dan MN) serta mengungkapkan perasaan marah (RF).

Partisipan umumnya merasakan dampak positif dari pemberian intervensi meskipun tidak semua perilaku asertif yang diajarkan dapat mereka terapkan dalam kehidupan sehari-hari. Lebih spesifik, beberapa partisipan (RF, LQ, KA dan ST) menyebutkan bahwa intervensi membuat mereka lebih berani mengungkapkan pendapat khususnya ketika berhadapan dengan teman, orang tua dan guru. Hal itu pun, cukup berdampak pada partisipasi mereka dalam kegiatan di kelas. Mereka menjadi lebih percaya diri untuk terlibat aktif dalam diskusi kelompok atau presentasi. Sementara itu FDZ berpendapat bahwa pelatihan membuat dia lebih berani menghadapi teman meskipun terkadang ia perlu menenangkan diri lebih dulu sebelum mempraktikan perilaku asertif tersebut. Kendati demikian, MN dan DO merasa ia belum mampu menerapkan secara maksimal pengetahuan yang diberikan selama kegiatan intervensi karena masih khawatir dengan respon yang diberikan lingkungan.

\section{DISKUSI}

Secara umum, hasil pengukuran menunjukkan bahwa intervensi menggunakan prinsip CBT terbukti efektif untuk meningkatkan perilaku asertif pada remaja awal terutama di aspek pengetahuan $(p=0.017)$ dan persepsi mengenai perilaku asertif terhadap orang tua $(p=0.002)$ dan guru $(p=0.019)$. Adapun hasil tersebut sejalan dengan penelitian sebelumnya yang dilakukan oleh Hasibuan dkk. (2018) yang mengemukakan bahwa intervensi menggunakan teknik cognitive restructuring dan pelatihan asertif terbukti secara efektif dapat meningkatkan perilaku asertif pada siswa. Dalam hal ini, kombinasi kedua teknik tersebut terbukti efektif untuk memberikan dampak positif pada aspek kognitif dan meningkatkan keterampilan siswa untuk berperilaku asertif. Berdasarkan hasil penelitian ini, mayoritas siswa menunjukkan perubahan pengetahuan mengenai perilaku asertif. Dalam hal ini, siswa mulai memahami apa itu perilaku asertif dan bagaimana berperilaku asertif secara tepat. Selain itu, hasil penelitian juga menemukan bahwa partisipan menunjukkan adanya perubahan persepsi dalam melakukan perilaku asertif. Dalam hal ini, partisipan berpikir saat ini mereka lebih mampu berperilaku asertif terhadap orang tua dan guru dibandingkan dengan saudara, teman laki-laki, atau teman perempuan. 
Berdasarkan hasil wawancara, partisipan menyebutkan bahwa mereka lebih berani untuk mempraktikan perilaku baru (asertif) setelah mendapatkan respon positif dari lingkungan misalnya mendapatkan respon positif dari ibu atau guru. Sedangkan teman atau saudara lebih sering memberikan respon negatif seperti mengejek. Sejalan dengan pendapat tersebut, Safran dan Sagal (1990, dalam Flecknoe \& Sanders, 2004) menyebutkan bahwa respon yang diberikan lingkungan berkontribusi dalam memelihara suatu perilaku. Dalam hal ini, respon yang diberikan orang lain merupakan bentuk konfirmasi terhadap keyakinan mereka. Sebagai contoh, jika seseorang memiliki keyakinan negatif dan mendapatkan respon negatif maka ia akan semakin yakin dengan pemikirannya, begitu juga sebaliknya.

Selain itu, kesuksesan dalam intervensi juga dapat dipengaruhi oleh karakteristik partisipan seperti, motivasi atau kesiapan klien menerima perubahan. Dalam hal ini, klien yang memiliki motivasi tinggi atau keinginan kuat untuk berubah memiliki kemungkinan yang lebih tinggi untuk mengalami kesuksesan dalam terapi (Whitlock, dalam Feinstein dkk., 2015). Feinstein dkk.(2015) juga mengemukakan bahwa kesiapan klien untuk menerima perubahan dan harapan untuk mendapatkan dampak positif dari perubahan tersebut juga memiliki peran yang signifikan dalam terapi. Pendapat tersebut sejalan dengan apa yang dialami oleh partisipan. Berdasarkan hasil wawancara setelah intervensi selesai, beberapa partisipan yang mengalami perubahan perilaku memiliki motivasi untuk berubah dan keinginan yang kuat untuk mendapatkan manfaat dari proses intervensi. Dengan demikian, hal tersebut menjadikan mereka bersemangat untuk berpartisipasi dan mempraktikan apa yang didapat selama intervensi.

Selain itu, hasil intervensi juga menunjukkan bahwa terjadi penurunan pengetahuan pada sesi follow-up. Adapun kemungkinan terjadinya penurunan perilaku tersebut disebabkan karena keterampilan asertif yang telah dipelajari sebelumnya tidak diterapkan atau dilatih dalam kehidupan sehari-hari oleh partisipan. Kolb dan Griffith (2009) menyebutkan keterampilan yang berkaitan dengan asertifitas harus dilatih dan dilakukan secara berulang kali agar kemampuan tersebut semakin dikuasai dan mampu diterapkan remaja meskipun berada di bawah tekanan. Sejalan dengan pendapat tersebut, beberapa partisipan yang belum menunjukkan perubahan perilaku cenderung tidak menerapkan atau melatih kemampuan asertif di luar jam intervensi.

Sementara itu, beberapa faktor lainnya dapat disebabkan karena kurangnya motivasi untuk berubah dan kurangnya kesadaran akan pentingnya perilaku baru tersebut (Feinstein dkk., 2015). Lebih jauh, tidak adanya respon positif yang diberikan lingkungan juga dapat menyebabkan tidak bertahannya perilaku baru yang ditampilkan oleh seseorang (Safran \& Sagal, 1990, dalam Flecknoe dan Sanders, 2004). Hal tersebut sejalan hasil observasi dan wawancara partisipan yang menunjukkan bahwa partisipan yang kurang menunjukkan perubahan cenderung kurang bermotivasi dalam mengerjakan tugas atau berbagi pengalaman selama intervensi. Sedangkan, beberapa partisipan lain juga ditemukan belum mampu menampilkan perubahan perilaku karena khawatir dengan respon yang diberikan oleh lingkungan.

Pada penelitian ini, juga ditemukan beberapa kekurangan seperti, kurang kooperatifnya partisipan dalam menjalankan tugas selama intervensi yang mengakibatkan beberapa tugas tidak dikerjakan dan sering kali tidak hadir dalam penelitian. Partisipan juga kesulitan untuk memahami beberapa kata yang tersaji di dalam modul karena bahasa atau kata belum pernah mereka temui sehingga peneliti perlu memberikan penjelasan tambahan kepada partisipan yang mana hal tersebut membuat waktu intervensi menjadi semakin lama. Sementara itu, pada sesi follow-up partisipan juga hanya diberikan 
lembar debriefing dan tidak diberikan rating perilaku sehingga perubahan persepsi pada situasi spesifik tertentu tidak diketahui. Selain itu, psikoedukasi mengenai perilaku asertif juga hanya diberikan pada guru kelas partisipan. Dengan demikian, jika partisipan naik ke kelas berikutnya, guru lainnya memiliki kemungkinan tidak mengetahui cara berperilaku asertif di dalam kelas.

\section{SIMPULAN}

Berdasarkan pemaparan di atas dapat disimpulkan bahwa intervensi dengan prinsip CBGT mampu meningkatkan perilaku asertif partisipan. Lebih spesifik, peningkatan signifikan terjadi pada aspek kognitif yang berkaitan dengan pengetahuan dan persepsi partisipan dalam melakukan perilaku asertif. Dalam hal ini, penerapan prinsip CBGT berperan dalam membantu partisipan mengubah pola berpikir mereka dari maladaptif menjadi adaptif. Sementara itu, perubahan pada aspek perseptif menunjukkan bahwa partisipan memandang dirinya dapat berperilaku asertif lebih mudah pada orang tua dan guru.

\section{SARAN}

Berdasarkan temuan yang diperoleh dari penelitian ini, maka peneliti merekomendasikan beberapa saran untuk penelitian selanjutnya. Secara praktikal, modul sebaiknya dibuat menggunakan bahasa yang lebih mudah dipahami khsusunya jika partisipan penelitian adalah remaja atau anak. Selain itu, perlu juga diberikan rating perilaku pada sesi followup sehingga dapat diketahui sejauh mana perubahan persepsi pada partisipan dalam melakukan perilaku asertif pada situasi tertentu. Tugas yang diberikan kepada partisipan juga harus lebih beragam seperti, menambahkan role play yang lebih banyak agar partisipan dapat berlatih bersama teman satu kelompok sebelum mempraktikan perilakunya secara langsung.
Pada proses assessment juga perlu ditambahkan screening yang dapat mengidentifikasi penyebab utama dari munculnya masalah. Dengan demikian, klien dapat diberikan intervensi yang sesuai dengan kebutuhannya. Selain itu, penelitian berikutnya juga sebaiknya memilih partisipan berdasarkan kesediaan sehingga orang-orang yang berpartisipasi dalam intervensi merupakan orang yang membutuhkan atau sangat menginkannya.

Sebagai tambahan, perlu juga diberikan psikoedukasi mengenai asertivitas dalam mengajar kepada seluruh guru di sekolah. Tujuannya adalah agar guru mengetahui bagaimana menerapkan perilaku asertif di dalam kelas. Beberapa hal yang dapat diajarkan kepada guru adalah cara menghadapi perilaku siswa yang tidak tepat, bagaimana menampilkan ekspresi dan menyampaikan informasi secara jelas, bagaimana cara mendengarkan, memuji orang lain dan mengatasi konflik di dalam kelas serta mengurangi ketakutan terhadap hukuman (Edwards, 2005; Zavertnik dkk., 2010, dalam Milovanović,2016).

Pada intervensi selanjutnya, peran serta orang tua juga dapat dilibatkan dalam pelaksanaan CBGT. Hal tersebut dirasa tepat karena respon dari lingkungan termasuk orang tua dapat memberikan dampak positif. Menurut Mendlowitz (1999, dalam Aydin, 2014) peran serta orang tua dapat memperkuat perilaku anak. Dalam hal ini, orang tua dapat mengawasi kemajuan terapeutik dan memberikan reinforcement terhadap perilaku baru yang muncul pada anak di dalam keseharian (Aydin, 2014).

\section{DAFTAR PUSTAKA}

Andayani, F. T., \& Mardianto, M. (2017). Perbedaan asertivitas antara mahasiswa etnis Minang dan etnis Batak. Jurnal RAP (Riset Aktual Psikologi Universitas Negeri Padang), 6(1), 33-44. http://ejournal.unp.ac.id/index.php/ps ikologi/article/view/6648. 
Asrowi, A., \& Muya, B. (2013). The effectiveness of asserive training to increase the communication skills of high school students in Surakarta. Dewantara, 1(1), 95-105.

Assigana, E., Chang, E., Cho, S., Kotecha, V., Liu, B., Turner, H., ... Stevens, S. M. (2014). TF-CBT triangle of life. Proceedings of the First ACM SIGCHI Annual Symposium on Computer-Human Interaction in Play - CHI PLAY '14, 9-16. http://doi.org/doi:10.1145/2658537.2 65868.

Aydin, P. A. (2014). Parental involvement in cognitive-behavioral therapy for children with anxiety disorders. Turk Psikiyatri Dergisi, 25(3), 181-189.

Çeçen-Eroğul, A. R., \& Zengel, M. (2009). The effectiveness of an assertiveness training programme on adolescents' assertiveness level. Ilkogretim Online, 8(2), 485-492. http://ilkogretim-online.org.tr.

Cheng, C., \& Chun, W. Y. (2008). Cultural differences and similarities in request rejection: A situational approach. Journal of Cross-Cultural Psychology, 39(6), 745-764. https://doi.org/10.1177/00220221083 23808.

Clark, D. A. (2013). Cognitive restructuring. The Wiley Handbook of Cognitive Behavioral Therapy, 1-22. https://doi.org/10.1002/97811185285 63.wbcbt02.

Duckworth, M. P. (2009). Assertiveness skills and the management of related factors. In W. T. O’Donohue \& J. E. Fisher (Eds.), General principles and empirically supported techniques of cognitive behavior therapy (pp. 124132). John Wiley \& Sons.
Eskin, M. (2003). Self-reported assertiveness in Swedish and Turkish adolescents: A cross-cultural comparison. Scandinavian Journal of Psychology, 44(1), 7-12. https://doi.org/doi:10.1111/14679450.t01-1-00315.

Feinstein, R., Heiman, N., \& Yager, J. (2015). Common factors affecting psychotherapy outcomes: Some implications for teaching psychotherapy. Journal of Psychiatric Practice ${ }^{\circledR}, 21(3)$, 180189.

http://doi.org/10.1097/PRA.0000000 000000064.

Fenn, K., \& Byrne, M. (2013). The key principles of cognitive behavioural therapy. Innovait: Education and Inspiration for General Practice, 6(9), 579-585. https://doi.org/10.1177/17557380124 71029.

Flecknoe, P., \& Sanders, D. (2004). Interpersonal difficulties. In $\mathrm{J}$. Bennet-Levy, G. Butler, M. Fennel, A. Hackman, M. Mueller, \& D. Westbrook, Oxford guide to behavioural experiments in cognitive therapy (pp. 393-409). Oxford University Press. https://doi.org/10.1093/med:psych/9 780198529163.001 .0001 .

Gaumer Erickson, A.S., Soukup, J.H., Noonan, P.M., \& McGurn, L. (2018). Assertiveness formative questionnaire technical report. http://www.researchcollaboration.org /uploads/assertivenessquestionnairei nfo.pdf.

Goswami, H. (2011). Social relationships and children's subjective well-being. Social Indicators Research, 107(3), $575-$ 
588.https://doi.org/10.1007/s11205011-9864-z.

Green, E. G., Deschamps, J. C., \& Paez, D. (2005). Variation of individualism and collectivism within and between 20 countries: A typological analysis. Journal of Cross-cultural Psychology, 36(3), 321-339. https://doi.org/10.1177/00220221042 73654.

Hasibuan, M. A. H., Purwanto, E., \& Japar, M. (2018). Effectiveness of group counseling cognitive behavior therapy cognitive restructuring technique and assertive skill training to improve assertive behavior students. Jurnal Bimbingan Konseling, 7(1), 55-62.

Howard, S., \& Johnson, B. (2004). Transitions from primary to secondary school: Possibilities and paradoxes [Disertasi tidak diterbitkan]. Australian Association for Research in Education.

Idrus, M. (2004). Kepercayaan eksistensial remaja Jawa:: Studi di Desa Tlogorejo, Purwodadi, Purworejo, Jawa Tengah [Disertasi tidak diterbitkan]. Universitas Gadjah Mada.

Ilkhchi, S. V., Poursharifi, H., \& Alilo, M. M. (2011). The effectiveness of Cognitive-Behavioral Group Therapy on self-efficacy and assertiveness among anxious female students of high schools. Procedia-Social and Behavioral Sciences, 30, 2586-2591. https://doi.org/10.1016/j.sbspro.2011 .10 .506 .

Kashani, P. A., \& Bayat, M. (2010). The effect of social skills training (assertiveness) on assertiveness and self-esteem increase of 9 to 11 yearold female students in Tehran,
Iran. World Applied Sciences Journal, 9(9), 1028-1032.

Kementerian Pendidikan Nasional. (2014). Konsep dan implementasi Kurikulum 2013.

https:/kemdikbud.go.id/kemdikbud/d okumen/Paparan/Paparan\%20Wame ndik.pdf.

Kolb, S. M., \& Griffith, A. C. S. (2009). "I'll repeat myself, again?!” Empowering students through assertive communication strategies. Teaching Exceptional Children, 41(3), 32-36. https://doi.org/10.1177/00400599090 4100304.

Milovanović, R. (2016). Assertiveness of prospective teachers and preschool teachers. Educația Plus, 16(2), 289303.

Ogunyemi, K. O., \& Olagbaju, O. O. (2020). Effects of assertive and aggressive communication styles on students' self-esteem and achievement in English language. Cross-

CulturalCommunication, 16(1), 96101.

Parray, W. M., \& Kumar, S. (2017). Impact of assertiveness training on the level of assertiveness, self-esteem, stress, psychological well-being and academic achievement of adolescents. Indian Journal of Health and Wellbeing, 8(12), 1476-1480.

Privitera, G. J., \& Delzell, L. A. (2019). Quasi-experimental and single-case experimental designs. Research Methods for Education, 333-370.

Ragelienè, T. (2016). Links of adolescents identity development and relationship with peers: A systematic literature review. Journal of the Canadian 
Academy of Child and Adolescent Psychiatry, 25(2), 97-105.

Ross, A., \& Willson, V. L. (2017). Basic and advanced statistical tests. Brill Sense.

Santoso, S. (2006). SSBBTI: SPSS statistik nonparametrik $+C D$. Elex Media Komputindo.

https://books.google.co.id/books?hl= en\&lr=\&id=DJvzSdAhauQC\&oi=fn d\&pg=PA2\&dq=Santoso, + S.+(2006) .+SSBBTI:+SPSS+Statistik+NonPar ametrik\%2B+CD.+Elex+Media+Ko mputindo.\&ots $=$ YLEyiHxR19\&sig= QAmAj4x0v2tNUbQ31XL_Vn_Y3k g\&redir_esc $=\mathrm{y} \# \mathrm{v}=$ onepage $\& \mathrm{q} \& \mathrm{f}=\mathrm{fal}$ se.

Sitota, G. (2018). Assertiveness and academic achievement motivation of adolescent students in selected secondary schools of Harari Peoples Regional State, Ethiopia. International Journal of Education and Literacy Studies, 6(4), 40-46.

https://doi.org/10.7575/aiac.ijels.v.6n .4p.40.

Speed, B. C., Goldstein, B. L., \& Goldfried, M. R. (2017). Assertiveness training: A forgotten evidence-based treatment. clinical psychology. Science and Practice, 25(1),e12216. https://doi.org/10.111 1/cpsp.12216.

Stewart, J.L, Christner, R.W, Freeman, A. (2007). An introduction to cognitivebehavior group therapy wih youth. In R.W. Christner., J.L. Stewart, A. Freeman, Handbook of cognitivebehavior therapy with children and adolescents (pp. 3-23). Routledge.

Tripathi, N., Nongmaithem, S., Mitkovic, M., Ristic, L., \& Zdravkovic, J. (2010). Assertiveness and personality: Cross-cultural differences in Indian and Serbian Male students. Psychological Studies, 55(4), 330-338. doi:10.1007/s12646010-0044-z.

Vagos, P., \& Pereira, A. (2019). Towards a cognitive-behavioral understanding of assertiveness: Effects of cognition and distress on different expressions of assertive behavior. Journal of Rational-Emotive \& CognitiveBehavior Therapy, 37(2), 133-148. doi.org/10.1007/s10942-018-0296-4.

Woolson, R. F. (2007). Wilcoxon signedrank test. Wiley Encyclopedia of Clinical Trials, 1-3. https://doi.org/10.1002/97804714624 22.eoct979.

Zulkaida, A. (2004). Pelatihan asertif untuk meningkatkan tingkah laku asertif pada mahasiswa (Pendekatan kognitif-perilaku)[Tesis, Universitas Indonesia]. Diunduh melalui http://lib.ui.ac.id/bo/uibo/detail.jsp?I $\mathrm{d}=20343556$ \&lokasi=lokal. 
Jurnal Psikogenesis Volume 9 No.1 Juni 2021 